\title{
A stressz és a szabadidősport jelenléte a mai emberek életében
}

\section{The Presence of Stress and Leisure Sports in the Life of Today's People}

\author{
A. KINCZEL \\ Debreceni Egyetem, Gazdaságtudományi Kar, antokincz@gmail.com
}

\begin{abstract}
Absztrakt. A mai embereket rendkívül sok dolog lefoglalja, mint például a munka, a család, a tanulás, ezért a szabadidejüket olyan tevékenységekkel próbálják eltölteni, amelyek elősegítik őket a relaxációban, megnyugvásban, feltöltődésben. Elmondható, hogy a mai világ emberei le vannak terhelve, sokkal stresszesebbek és idegesebbek, próbálnak a legjobban teljesíteni, hogy megfelelően éljenek. Sok embernek nehezére esik a kommunikáció, a közösségi élet. Rengetegen vannak, akik rákényszerülnek arra, hogy otthonról is dolgozzanak, mivel a projektek és többhetes határidők nem várnak. Ezek mellett még rengeteg dolgot el kell végezni, kell foglalkozni a gyermekekkel, kell szórakozni, figyelni kell az egészségre, háztartást kell irányítani stb., így kevés idô marad arra, hogy azt végezzék az emberek amit igazából szeretnek. A kutatásomban felmértem a romániai és magyarországi lakosok szabadidôs szokásait, a sportban való aktivitásukat ugyanakkor az aktív rekreációs tevékenységekhez való hozzáállásukat ( $N=273)$. Az eredmények azt mutatják, hogy még mindig a passzív szabadidős tevékenységek (tv nézés, olvasás, zenehallgatás, internetezés) a legnépszerúbbek az emberek körében, bár legtöbben ülő munkát végeznek. Azok az emberek, akikszabadidejükben sportolnak, sokkal felfrissültebbnek érezték magukat, továbbá jobb volt a hangulatuk, pozitívabban gondolkodtak. Föleg azok a sportok kerülnek elötérbe, amelyeket az emberek a szabadban, a parkokban üzhetik.
\end{abstract}

Abstract. Today's people are extremely busy with a lot of things, such as work, family, learning, so they try to spend their free time with activities that promote them in relaxation, reassurance, recreation. It can be said that the people of today's world are burdened, more stressed and nervous, trying to do the best they can to live properly. A lot of people have a hard time communicating, community life. There are a lot of people who are forced to work from home, as projects and weeks' deadlines don't wait. Besides, there are many things to be done, children need to be dealt with, you have to have fun, you have to pay attention to health, you have to run a household, etc., so there is little time for people to do what they really love. In my research, I assessed the leisure habits of the inhabitants of Romania and Hungary, but their attitude to active reclamation activities ( $N=273)$ was their activity in sport. The results show that passive leisure activities (watching TV, reading, listening to music, internet) are still the most popular among people, although most of us do sedentary work. People who play sports in their spare time felt more refreshed, and they had a better mood, more positive. The sports that people can play outdoors and in parks come to the fore. 


\section{Bevezetés}

Korunkat a teljesítmény és munkakényszer jellemzi, melynek eredményeként a stressz, a stressz eredetű betegségek egyre több embert érintenek, mely egyre nagyobb terheket ró az egészségügyi ellátórendszerre [17] [2] [21] [22]. A fizikai inaktivitásból fakadó betegségek terhe is egyre komolyabb gazdasági probléma, melyet a betegségteher vizsgálatok a középpontba állítanak [20,46]. A stressz környezeti megközelítése szerint életünk minden területén számos stresszornak vagyunk kitéve, azonban a munka életünkben betöltött központi szerepe miatt a munkahelyi stressz és az ezt kiváltó stresszorok kutatása mindig kiemelt fontosságú volt. Azok a munkahelyi pszichoszociális jellemzők, amelyek stresszt okoznak, számtalan forrásból származhatnak. Ilyenek lehetnek például a túl magas vagy túl alacsony követelmények/elvárások, a hétvégi munka, a munkahelyi bizonytalanság, a segítő munkatársi kapcsolatok hiánya, a felettestől kapott támogatás hiánya, a nem megfelelő fizetés, megnövekedett túlórák vagy a váltott műszak [47]. A munkahelyi stressz okozta krónikus feszültség számos olyan megbetegedés előfordulási kockázatát növeli, mint amilyen például a fertőző betegségek, a depresszió vagy a szorongásos megbetegedések [13] [27].

Napjainkban a betegségek prevencióján túl fokozott igény jelenik meg az emberek életminőségének javítása iránt [11] [15]. Az életminőséggel és jólléttel, valamint a boldogsággal kapcsolatos szakirodalmak már régóta megjelennek a hazai és nemzetközi kutatásokban egyaránt [11] [12] [23] [41] [29] [31]. A társadalom igényt támaszt a jó életminőség iránt, mely nem csak az egészséges, de a beteg populációban is központi kutatási téma [30] [37] [40]. Az életminőség [26] szerint „az emberi tapasztalat összes aspektusát magába foglalja" amely biztosíthatja az egyén lelki, fizikai és szociális elemeit a jólétnek.

A szabadidősportnak rengeteg pozitív hatása ismert az ember testi, lelki és szociális közérzetére, melyet több hazai [25] [34] [48] [51] [52] és nemzetközi [16] [3] szakirodalom is igazolt. A sport egyik kiváló eszköze lehet a munkahelyi egészségfejlesztésnek, mivel hatékonyan csökkentheti a stresszt és pozitívan hat a munkavállalók terhelhetőségére. Ez az irányvonal jól illeszthető a cégek társadalmi felelősségvállalás jegyében hozott intézkedéseikhez, mely egyre népszerűbb kutatási terület napjainkban $[53,54]$.

\section{A kutatás ismertetése}

A szabadidő eltöltés vizsgálatára kérdőíves kutatást terveztem, melyben a vizsgálatban részt vevő személyek szabadidős preferencia-rendszerére voltam kíváncsi. A rekreációs szokások területén az aktív és passzív tevékenységi formák gyakoriságát is vizsgáltam. Rákérdeztem a stressz szintre és az általuk alkalmazott stresszoldó módszerekre, technikákra. A kérdőívet online formában töltötték ki, a válaszadás önkéntes volt $(\mathrm{N}=273)$. Az adatokat excel segítségével dolgoztam fel.

\section{A minta bemutatása}

A kitöltők legnagyobb részét (68\%) a fiatal felnőttek teszik ki: a 19-25 év közöttiek, a további válaszadók 16,8\%-a 18 év alatti, 4,4\%-a 26-30, 2,9\%-a 31-35, szintén 2,9\%-a 36-40, 1,8\%-a 46-50 év közötti 
ugyanakkor 1,8\%-a 56 év fölötti, 1,5\%-a 41-45 év közötti, 0,7\%-a pedig 51-55 év közötti válaszadók voltak.

\section{Az Ön kora:}

\section{3 válasz}

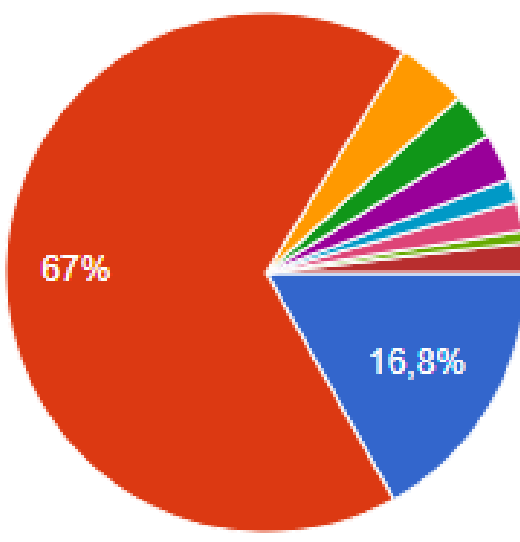

$-18$

$19-25$

26-30

31-35

$36-40$

$41-45$

46-50

$51-55$

$56-$

\section{1. ábra. A válaszadók életkora}

Összeadva azoknak a válaszadóknak a számát akik tanulók és azokét, akik ülő munkát végeznek az eredmény 220, ami a 81,3\%-át teszi ki a kitöltőknek. A válaszadók nagy részét a hosszan tartó napi ülőidő jellemez, mely rizikótényező az életmódfüggő betegségek kialakulásában [20]. Vannak akik vegyes munkát (fizikai és ülő munka) is végeznek, az ő számuk kevesebb, 29 fő és a fizikai munkát végzők 22 fő.

Milyen jellegü munkát végez?

273 válasz

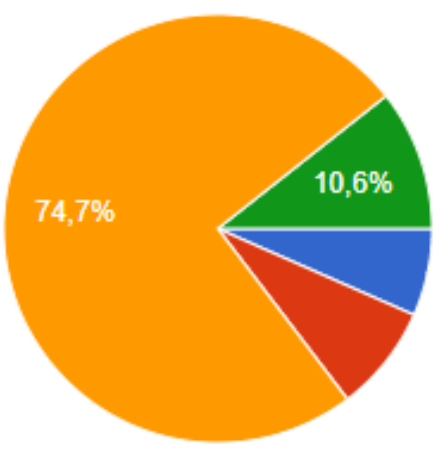

Ülömunka

Fizikai munka

Tanuló vagyok

Vegyes (ülỏ és fizikai munkát is végzek)

2. ábra. A válaszadók milyen jellegü munkát végeznek 
A válaszadók közül 191 fő $(71,1 \%)$ nő, míg 79 fő $(28,9 \%)$ férfi válaszadó volt.

\section{Az Ön neme:}

273 válasz

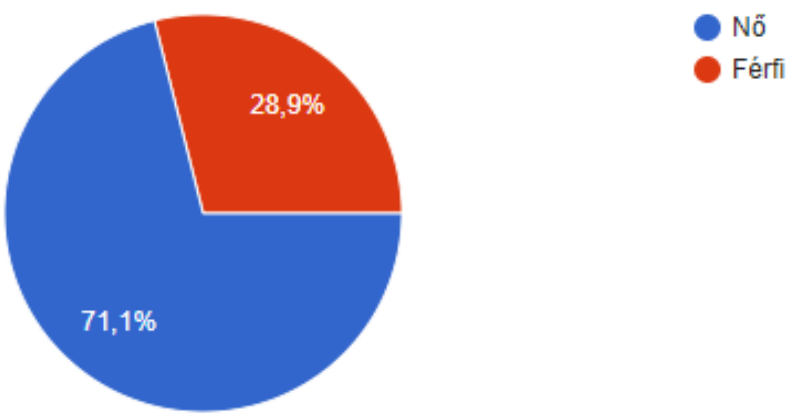

3. ábra. A válaszadók neme

\section{A stresszel kapcsolatos kutatás eredményei}

Kíváncsi voltam arra, hogy a válaszadóknak milyen a stressz előfordulása a mindennapi életükben. A kérdésre: hogy "a stressz mennyire van jelen az életében" egy egytől-ötös likert skálán kellett válaszolniuk, ahol egy az egyáltalán nem jellemző, 2 a kismértékben, 3 a közepesen, 4 a jellemző és 5 szinte mindig jellemző volt. A válaszadók életében markánsan jelen van a stressz, hiszen az átlag=4,57 volt, melyhez alacsony szórás: 0,456 társult, ami azt mutatja, hogy igen egységesek voltak a válaszok. Mik a leggyakrabban használt stresszoldó módszerek az Ön életében? (1-5-ös likert skálán kellett értékelni a leggyakrabban használt módszereket, ahol 1= egyáltalán nem alkalmazom, 5= leggyakrabban alkalmazom) Az 1. sz. táblázat szemlélteti, hogy a sportot és a fizikai munkát alkalmazzák leginkább stresszoldás céljából. A harmadik legnépszerűbb stresszoldó módszernek a masszázs bizonyult. Több kutatás is bizonyította, hogy a masszázsnak nem cask az ízületi hajlékonyság javításában van szerepe, hanem a stresszoldásban is [14] [4]. A fürdőzés, a wellness szolgáltatások és az egyéb kategória kapott még magas átlagértéket. Magyarországon a fürdők nem csak a turizmusban de a rekreációban is egyre nagyobb szerepet játszanak, nem csak a víz és az úszás jótékony hatása miatt, de a fürdők wellness elemeivel is az egészségmegőrzést helyezik a fókuszba, melyet több hazai kutatás megerősít [43] [33] [38] [1]. A wellness szolgáltatások a testi-lelki és szociális jó közérzet biztosítására hivatottak [42], így alkalmasak a stress kezelésére is, ami miatt a wellness utazások kereslete napjainkban bővült. Az egyéb kategóriába a zenehallgatás kapta a leggyakoribb említést.

\begin{tabular}{|l|l|l|}
\hline stresszoldó módszer & átlag & szórás \\
\hline sportolás & 4,2 & 0,456 \\
\hline
\end{tabular}




\begin{tabular}{|l|l|l|}
\hline $\begin{array}{l}\text { fizikai aktivitás (kerti munka, } \\
\text { házimunka) }\end{array}$ & 4,1 & 0,321 \\
\hline masszázs & 4,0 & 0,989 \\
\hline jóga & 2,9 & 1,211 \\
\hline meditáció & 2,1 & 1,231 \\
\hline utazás & 3,4 & 1,234 \\
\hline wellness & 3,8 & 0,982 \\
\hline fürdő & 3,9 & 0,734 \\
\hline autogén training & 2,1 & 0,121 \\
\hline egyéb & 3.7 & 0,654 \\
\hline
\end{tabular}

1. táblázat. A stressz kezelésére alkalmazott módszerek alakulása a felmért mintában

\section{A szabadidőeltöltési szokásokkal kapcsolatos eredmények}

A szabadidejüket az emberek leginkább passzív pihenéssel töltik. Nagyon népszerű a média világa, amit bizonyít a kutatásom is, hiszen a válaszadók 68,9\%-a a szabadidejét internetezéssel (számítógép, mobil, tablet) tölti. A második legnépszerübb időtöltés is a passzív pihenéshez tartozik, hiszen $62,6 \%$-a a válaszadóknak Tv-nézéssel vagy zenehallgatással próbálja kipihenni a fáradalmakat és próbálnak újra feltöltődni. 49,8\%-a az embereknek szereti passzív pihenéssel, lustálkodással az ágyban eltölteni az idejét. A kutatás egybevág más hazai kutatási eredményekkel, ahol a fiatal felnőttek mintájában szintén a passzív szabadidős tevékenységek domináltak [40] [32] [7] [8] [28] [55] [56]. Ezek után jön be az aktív szabadidőeltöltés, 48,4\%-a a válaszadóknak a szabadidejükben sportol. Népszerű szabadidőeltöltés még az olvasás vagy meditáció 43,2\%, a házimunka (takarítás, fôzés, mosás, kukaürítés, kertészkedés stb.) 38,8\%, háziállattal való sétálás, játszás $31,9 \%$, a tanulás $28,6 \%$, a vásárlás $25,3 \%$, míg kevésbé népszerű a sporteseményeken való részvétel sportolóként 19,4\%, a vallásos tevékenységek (templomba járás, egyházmegyei programokon való részvétel, hittanóra stb.) 18,3\%, egészségmegőrzés (szauna, fürdő) 15,4\%, muzsikálás 8,8\%, horgászat 5,5\%, vadászat 1,1\%. A válaszadók nem mindig ugyanazokat a szabadidős tevékenységeket végzik, több választ is jelölhettek, ezért jöttek ki ezek a százalékos arányok. Ezekből a számadatokból elmondható, hogy bár az emberek 83,1\%-a ülő munkát végez vagy mindkettőt (ülő és fizikai munkát is), mégis kevés időt töltenek aktívabb szabadidős tevékenységekkel. Érhető, hogy aki fizikai munkát végez, az szabadidejében inkább olvas, pihen, zenét hallgat.

\subsection{Sportolási szokások vizsgálatának tapasztalataiból}

A válaszadók 64,5\%-a sportol, vagyis végez testnevelés órán kívüli tevékenységet, melynek hossza minimum fél óra. Azok száma, akik nem sportolnak, 35,5\%-ék. Ez az érték jobb, mint amit a hazai mért adatokról korábban publikált az Eurobarométer 2018-as tanulmánya, mely szerint az unióban a lakosságnak csupán 7\%-a sportolt heti 5 vagy annál többször, 33\%-uk heti 1-4 alkalommal, míg az 
ennél ritkábban sportolók aránya 14\% volt. 46\%-os volt azoknak a felnőtteknek az aránya, akik soha nem végeznek rendszeres sporttevékenységet [18].

Sportol-e? (Igen= testnevelés órán kivüli tevékenység, egy alkalom hossza: minimum fél óra.)

273 válasz

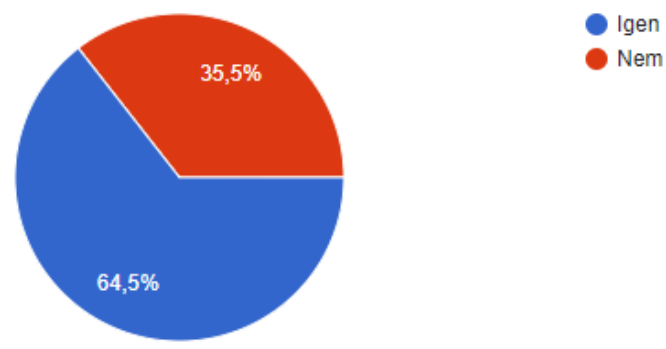

4. ábra. A válaszadók sportolási szokása

Az 5. ábra szemlélteti azt, hogy a megkérdezettek ismerik-e a környezetükben található sportolási lehetőségeket. Azok közül is, akik nem sportolnak, valószínúleg sokan tisztában vannak a környezetükben található sportolási lehetőségekkel (egyesület, kondipark, edzőtermek, stb.), mint ahogyan a számok mutatják (91,9\%), csupán nem veszik igénybe a lehetőségeket.
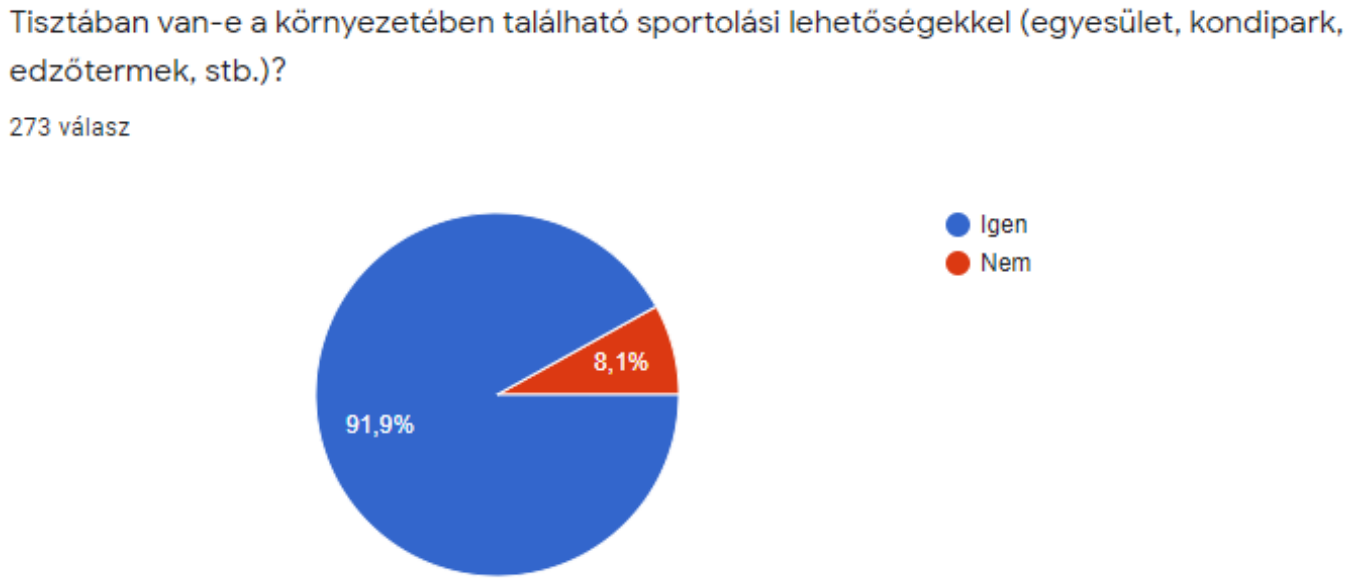

5. ábra. A megkérdezettek mennyire vannak tisztában a környezetükben található sportolási lehetöségekkel

A legelterjedtebb sportok a gyaloglás, túra, nordic-walking, melyeket 41,8\%-ban űzik az emberek. A természeti sportok szintén a képességfejlesztésben de a stressz oldásban is fontos szerepet játszanak [9].

A futás 36,6\%, a kerékpár 34,4\%, fitness 21,6\%, futball 15,8\%, úszás 13,9\%, testépítés 13,6\%, míg kevésbé igénybevett sportok a kézilabda 7\%, az aerobik 6,2\%, darts, bowling 5,5\%, sporttánc 5,1\%, futsal, röplabda 4,8\%, kosárlabda, tollaslabda 4,4\%. Az olyan sportágakat, mint a gördeszkázás, ijászat, karate, lovaglás, jégkorong, vívás, síelés, extrém sportok (hegymászás, sárkányrepülés stb.) mindössze 1-10 ember végzi, mivel ezek költségesek és a motivációban a kihívás, az új élmények fokozottan jelennek meg [6] [36] [37] [50]. 


\subsection{Sportolás helyszínei}

Ahogyan látjuk népszerúek azok a sportágak, amelyeket az emberek a szabadban, parkokban végezhetnek , mint például a gyaloglás, túra, futás, kerékpár, így egyértelmű, hogy a válaszadók közül a legtöbben a szabadban, a parkokban szeretnek sportolni, ők adják a válaszadók 21,6\%-át. Bizonyára sokan szeretnének nyugodt környezetben sportolni, szeretnének kiszabadulni a városi életből. Ilyenkor az emberek jobban oda tudnak figyelni önmagukra, friss levegőn vannak, jobban kikapcsolódnak. Sokan nem szeretnek kimozdulni, közösségekbe járni, előnyben részesítik az otthont, mint sportolási helyszínt, mely egyben költséghatékony is a válaszadók 20,9\%-a nyilatkozta ezt. A megkérdezettek 17,6\%-a fitness-wellnes központban, 16,1\%-uk egyesületben, 13,2\%-uk iskolában/munkahelyen/egyetemen végez testmozgást, 10,6\%-uk pedig iskolába/munkahelyre/egyetemre menet sportol. Az Eurobarométer [18] kutatása szerint a szabadidő sportolás leggyakoribb helyszínei a szabadban (40\%), az otthon (32\%) és a munkába vagy iskolába menet (32\%) volt az uniós állampolgárok között.

\section{Hol szokott sportolni?}

273 válasz

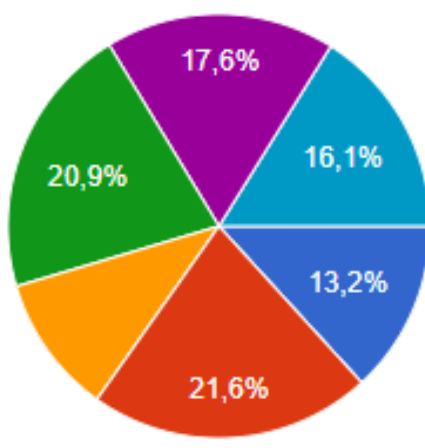

Iskolában/egyetemen/munkahelyen

Szabadban, parkokban

Iskolába/egyetemre/munkába menet

Otthon

Fitness-wellness központban

Egyesületben

6. ábra. Sportolási helyszínek

A megkérdezettek motivációja sokszínű volt, több választ is megjelölhettek. A válaszadók leginkább azért szoktak sportolni, hogy fenntartsák az egészségüket és a jó közérzetüket (67\%), ugyanakkor a sport boldoggá teszi őket (56\%), továbbá azért, hogy fogyjanak, javítsanak a külső megjelenésükön (51\%), de izgalmas, szórakoztató tevékenységet (50\%) is sokan jelölték. A külső tényezők, azaz, azért mert mások elvárják tőlük, nagyon kevesen sportolnak (21\%).

\subsection{Sport és társaság}

Van, aki szívesen jár egy közösségbe, egyesületbe sportolni, mivel olyan emberek vannak körülötte olyankor, akik motiválják, jól érzi magát velük. Sokan csak kevés személyel együtt, mint például egy barát/barátnő szeretnek sportolni vannak akik egyedül. Számukra a másik személy nyújt motivációt. Van akik az edzőjükkel szeretnek együtt mozogni, hiszen olyankor egy olyan személy van mellettük, akiben megbíznak, felnéznek rá, tisztelik és bizonyára nagyon jól tudja őket motiválni is. 
A közösségben való sportolás egy eszköz lehetne azon emberek számára, akik nehezen tudnak beilleszkedni egy közösségbe, akik szoronganak, nincs elég önbizalmuk. Mennyire könnyebb lenne elfogadniuk saját magukat, ha látnák, hogy mennyire sokan vannak olyan emberek, akik nem elégedettek a kinézetükkel, akik fogyni szeretnének, vagy csupán társaságra vágynak. Az emberek nem szeretik egyedül érezni magukat, szeretnek társaságban lenni. A csoport ereje, a jó társaság, az egymás ösztönzése még több erőt adna és még jobban megszeretettné a sportot. Sok problémára megoldás lehetne, ha az emberek egy olyan közösségben kezdenének el sportolni, ahol barátokat is találnak, ahová szívesen mennek, ahol egy olyan személy az edző, aki egyben motiválja is őket, tanácsokat add, ugyanakkor barátként tekint rájuk.

\section{Hogyan/Kivel szeret sportolni? (Több választ is jelölhet.)}

272 válasz

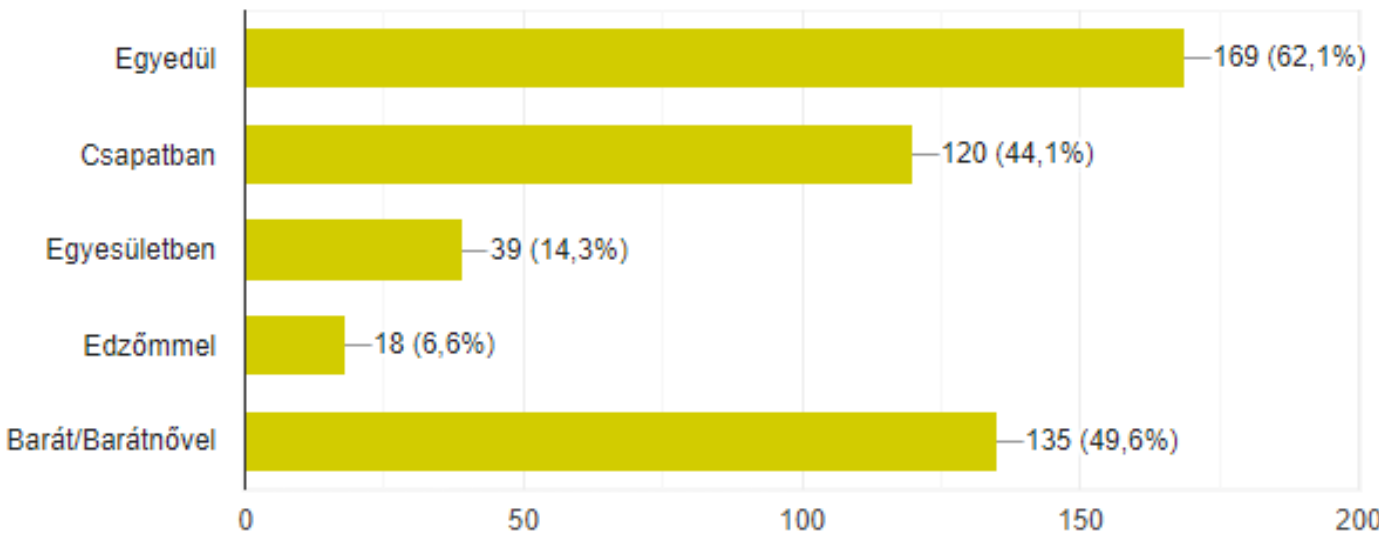

7. ábra. Sport és társaság

\section{4. Életmóddal kapcsolatos kutatások eredményei}

Az egészséges életmódnak az elemei azok a tevékenység és magatartásformák, melyek a szervezet optimális működését biztosítja. Az életmód megjelenik mind a munkával, mind a szabadidővel kapcsolatos magatartási mintázatokban, és (egyéni alapon) az aktivitásban, attitűdökben, érdeklődésben, véleményekben, értékekben és a jövedelem felhasználásában egyaránt. Tükrözi az emberek ön-képét és ön-ábrázolását, azt a módot, ahogy magukat látják, és ahogy képzelik, mások milyennek látják őket. Az életmód a motivációk, késztetések, és szükségletek keveréke, és olyan tényezők befolyásolják, mint a kultúra, a család, a referenciacsoportok és a társadalmi osztály" [10]. Könnyen összekapcsolható a helyes életmód és a sport fogalma. Az életmódbeli tényezők közül kiemelkedő az egészséges és rendszeres táplálkozás, valamint a rendszeres fizikai aktivitás. A WHO becslése szerint a testmozgás hiánya évente mintegy 2 millió halálesethez vezet. Aki helyes életmódót szeretne élni, az valószínúleg időt fog szánni a testmozgásra, mivel a testmozgásnak rengeteg pozitív hatása van. A sport nemcsak a testi, hanem a lelki egészségünknek is nagyon jót tesz. A rengeteg szív és érrendszeri betegségek mellett figyelembe kell venni a mentális betegségek megsokszorozódását is, a mai emberek életében. Nemzetközi szinten az Európai Unió (EU) és a WHO által közösen kidolgozott és 
az Európai Közösség Bizottsága által kiadott Zöld Könyv a mentális betegségekről hívja fel a figyelmet, és társadalmi szintű lépéseket ajánl [19]. A "Sport XXI. Nemzeti Sportstratégia” ugyancsak komoly figyelmet fordít a témának, és a 2007-2020 közötti évekre vázolja fel a teendőket és határozza meg a cselekvési irányokat [49]. Ezek a tények is azt bizonyítják, hogy ez valójában komoly probléma, amely egyre elterjedtebb.

\section{Pozitív változás sport után}

Megkérdeztem az embereket, hogy észrevettek-e valamilyen pozitív hatást magukon sportolás után. A válaszadók 69,2\%-a felfrissültebbnek érezte magát, 61,9\%-ának jobb volt a hangulata, pozitívabban gondolkodott, 28,6-ának sokkal könnyebb volt tanulni, dolgozni, 28,2\%-a jobban tudott összpontosítani a feladataira, míg csupán 8,8\%-uk nem vett észre pozitív változást, ami azért lehetett, mivel nem sportol vagy nem eleget ahhoz, hogy pozitív változást vehessen észre.

\section{Észrevett saját magán valami pozitiv változást miközben/miután sportolt? (Több választ is jelölhet.) \\ 273 válasz}

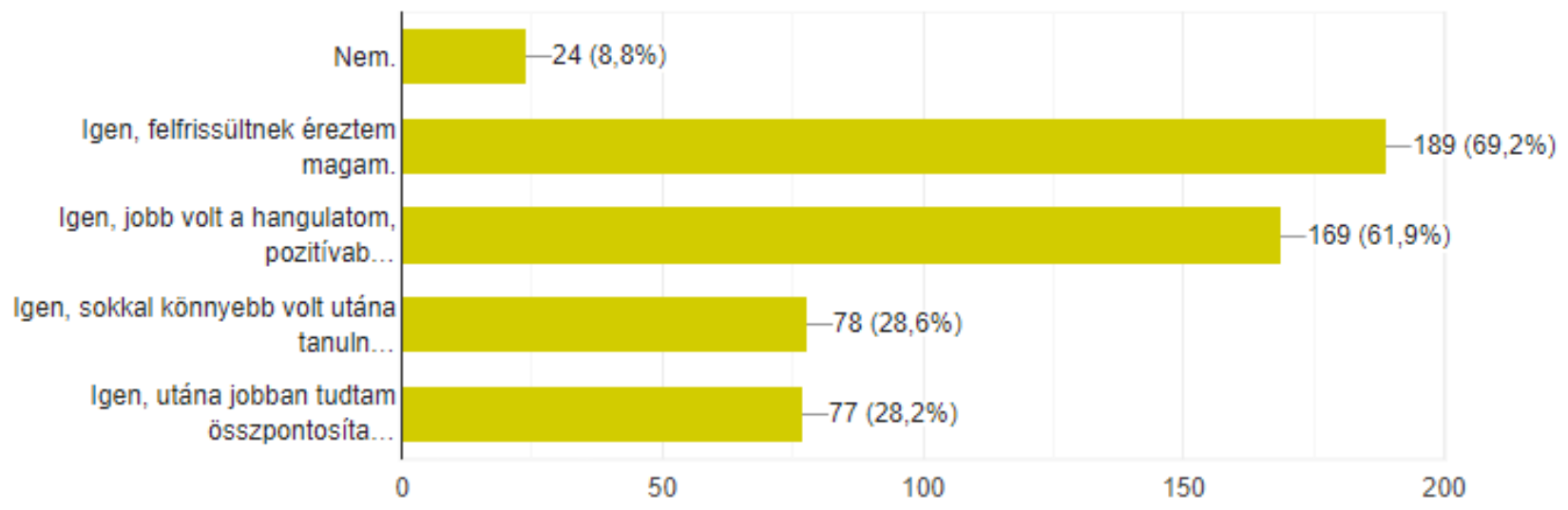

8. ábra. Pozitív változás sportolás közben/után

\section{Konklúzió}

Ez a kutatás is megerősítette, hogy az emberek többsége ülő munkát végez, melyhez arányosan kevesebb sporttal és fizikai aktivitással eltöltött idő társul. A szabadidejüket olyan tevékenységekkel töltik, melyek passzív szabadidős tevékenységek. Ezeknek az embereknek több időt kellene szánni az aktív szabadidős tevékenységekre [5]. A fizikai aktivitás és sportolás ösztönzése a munkahelyeken is fontos, mivel egészségesebb és teherbíróbb munkaerőt jelentve a termelékenység növekedéséhez is hozzájárul. A testnevelési és sportprogramok ösztönzését [24] emeli ki több szerző, mivel a sport elősegíti a kikapcsolódást, felfrissülést, jobb közérzetet biztosít ezért segít javítani az emberek közérzetén, csökkenti stressz szintet és prevenciós eszközként funkcionál számos életmódfüggő betegség esetében. 


\section{Köszönetnyilvánítás}

A publikáció elkészítését az EFOP-3.6.2-16-2017-00003 számú projekt támogatta. A projekt az Európai Unió támogatásával, az Európai Szociális Alap társfinanszírozásával valósult meg.

\section{Hivatkozások}

[1] Barta, G. - Pálinkás, R. - Müller, A. (2011), The Role of the Saliris Thermal Spa's bath in the tourism and recreation, Acta Academiae Paedagogicae Agriensis Nova Series: Sectio Sport 38. pp. 5-13.

[2] Béjean, S. - Sultan-Taïeb, H. (2005), Modeling the economic burden of diseases imputable to stress at work, The European journal of health economics, 6(1), 16-23.

[3] Bendíková, E. - Marko, M. - Müller, A. - Bába, É. Bácsné (2018), Effect of Applied HealthOriented Exercises in Physical and Sport Education on Musculoskeletal System of Female Students, Acta Facultatis Educationis Physicae Universitatis Comenianae 58 : 2 pp. 84-96.

[4] Bíró, M. - Bendíková, E. - Marko, M. - Tütünkov-Hrisztov, J. - Lenténé, Puskás A., A masszázs, mint szolgáltatási kategória megjelenése az Észak-alföldi szállodák kínálatában, KÜLÖNLEGES BÁNÁSMÓD 5 : 4 pp. 21-32. , 12 p. (2019)

[5] Bíró, M. - Müller, A. (2017), Aktív pihenés, rekreáció = Active relaxation, recreation. In: Dobos, Anna; Mika, János (szerk.) Természeti és kultúrtörténeti értékek Eger térségében = Natural and cultural heritage in the Eger Region. Eger, Magyarország : Líceum Kiadó, (2017) pp. 128-130. , 3 p.

[6] Boda, E. - Bácsné Bába, É. - Müller, A. (2018), Motiváció vizsgálata a kalandpark-látogátók körébén, International Journal Of Engineering And Management Sciences / Műszaki És Menedzsment Tudományi Közlemények $3: 3$ pp. 106-126. , 21 p. (2018)

[7] Boda, E. - Honfi, L. - Bíró, M. - Révész, L. - Müller, A., (2015), A szabadidő eltöltésének és a rekreációs tevékenységek vizsgálata egri lakosok körében, ACTA ACADEMIAE PAEDAGOGICAE AGRIENSIS NOVA SERIES: SECTIO SPORT 42 pp. 49-62.

[8] Boda, E. J. - Bácsné, Bába É. - Laoues-Czimbalmos, N. - Müller, A., Rekreációs fogyasztói szokások vizsgálata magyar fiatal felnőttek körében, KÜLÖNLEGES BÁNÁSMÓD 5 : 4 pp. 33-44. , 12 p. (2019)

[9] Borbély, A. - Müller, A. (2015), Sport és turizmus, Debrecen, Magyarország: Campus Kiadó (2015), 110 p. ISBN: 9789639822368

[10] Business Dictionary. Retrieved from http://www.businessdictionary.com/definition/lifestyle.html (2017. 07. 30.).

[11] Campbell, A. (1976), Subjective measures of well-being, American psychologist, 31(2) p. 117.

[12] Cobb, C. W.-Rixford, C. (1998), Lessons learned from the history of social indicators (Vol. 1), San Francisco: Redefining Progress. 
[13] Cohen, F., Kemeny, M.E., Zegans, L.S., Johnson, P., Kearney, K.A., és Stites, D.P. (2007), Immune function declines with unemployment and recovers after stressor termination, Psychosomatic Medicine, 69 (3): 225-34.

[14] Csörgő, T. - Bíró, M. - Kopkáné, Plachy J. - Müller, A., Masszázsterápia hatásának vizsgálata hatvan év feletti nők körében, Acta Academiae Paedagogicae Agriensis Nova Series: Sectio Sport 40 pp. 5-16.

[15] Daniels, K. - Harris, C. (2000), Work, psychological well-being and performance. Occupational Medicine - Oxford, 50, 304-309

[16] Dobay B., Müller A., \& E. Bendíková (2017), Adult Health in Terms of Selected Lifestyle Factor, Disputationes Scientificae Universitatis Chatholicae In Ruzomberok 17 : 4 pp. 32-39. , 8 p. (2017)

[17] Ember, A. (2009), A munkahelyi stressz, mint a leggyakoribb modern foglalkozási megbetegedés, Acta Sana, 4(2), 15-23.

[18] Eurobarometer, 2018 Special Eurobarometer 472, Sport and physical activity, https://www.loketgezondleven.nl/sites/default/files/2018-

12/Eurobarometer_472_PhysActivSports2018.pdf

[19] Európai Közösség Bizottsága (2006), Zöld Könyv, A lakosság mentális egészségének javítása, Az Európai Únió mentális egészségügyi stratégiájának kialakítása 2005-Budapest.

[20] Gabnai, Z. - Müller, A. - Bács, Z. - Bácsné, Bába, É. (2019), A fizikai inaktivitás nemzetgazdasági terhei, Egészségfejlesztés 60 : 1 pp. 20-30. , 11 p. (2019)

[21] Hassard, J. - Teoh, K. - Visockaite, G. - Dewe, P. - Cox, T. (2017), The cost of work-related stress: A systematic review. Journal of Occupational Health Psychology. doi: 10.1037/ocp0000069

[22] Hassard, J. - Teoh, K. R. - Visockaite, G. - Dewe, P. - Cox, T. (2018), The financial burden of psychosocial workplace aggression: A systematic review of cost-of-illness studies. Work \& Stress, 32(1), 6-32.

[23] Hegedűs, R. (2001), Szubjektív társadalmi indikátorok-szelektív áttekintés a téma irodalmából, Szociológia Szemle, 2, p. 58-71.

[24] Hidvégi, P. - Bíró, M. - Müller, A. - Váczi, P. (2017), Testnevelési program a munkahelyi egészségfejlesztésben, Acta Academiae Paedagogicae Agriensis Nova Series: Sectio Sport 44 pp. 115-138. , 24 p. (2017)

[25] Juhász I., Kopkáné Plachy J., Kiszela K., Bíró M., Müller A., \& Révész L. (2015), Idôskorúak rekreációs fizikai aktivitásának hatása a kardiorespiratorikus rendszerre, Magyar Sporttudományi Szemle 16: 63 pp. 4-8. , 5 p. (2015)

[26] Káló, Z. - Péntek, M. Az életminőség mérése, In: Gulácsi László (szerk.), Egészséggazdaságtan. Medicina, Budapest, 2005: 161-189.

[27] Kopp M.S., Stauder A., Purebl Gy., Janszky I., Skrabski Á. (2007a), Work stress and mental health in a changing society, European Journal of Public Health, 18 (3): 238-244.

[28] Laoues-, Czimbalmos N. - Dobay, B. - Müller, A., Examination of the Leisure Time-Related Consumption Habits of Young People With Disabilities with Special Emphasis on Sports, SELYE ESTUDIES $10: 2$ pp. 34-45. , 12 p. (2019) 
[29] Lengyel, A. - Kovács, S. - Müller, A. - Lóránt, D. - Szőke, Sz. - Bácsné Bába, É., Sustainability and Subjective Well-Being: How Students Weigh Dimensions, Sustainability 11 : 23 Paper: 6627 (2019)

[30] Mészáros Á. (2006), Életminőség-mérés asthma bronchialéban, LAM, 16: 353-359.

[31] Michalkó G. (2010), Boldogító utazás: a turizmus és az életminőség kapcsolatának magyarországi vonatkozásai, MTA Földrajztudományi Kutatóintézet. Budapest. p.16-40.

[32] Mosonyi, A. - Könyves, E. - Fodor, I. - Müller, A., (2013), Leisure activities and travel habits of College students in the light of a survey, APSTRACT - APPLIED STUDIES IN AGRIBUSINESS AND COMMERCE $7: 1$ pp. 57-61.

[33] Müller A. - Kerényi E., (2009) Trendek és fogyasztói magatartás az egészségügyben. Egészségügyi marketing és telekommunikáció c. konferencia kiadványkötete, Mátrai Gyógyintézet, Magyarország, Kékestető. pp. 11-19.

[34] Müller A., \& Bácsné Bába É. (2018), Az egészséges életmód és a sport kapcsolata, Létavértes, Magyarország: Létavértes SC '97 Egyesület (2018), 96 p. ISBN: 9786150031897.

[35] Müller, A - Bolega, S - Gabnai, Z - Bácsné, Bába É - Pfau, C (2018), A Bmx, és égyéb extrém sportok választásánák motivációs tényezői. International Journal of Engineering and Management sciences / Mûszaki és menedzsment tudományi közlemények 3 : 4 pp. 426-441.

[36] Müller, A. - Bácsné Bába, É. - Oláh, J.- Pfau, C. - Molnár, A. (2019), Lovas szolgáltató létesítmények összehasonlító elemzése az Észak-alföldi régióban. International Journal of Engineering And Management Sciences / Múszaki És Menedzsment Tudományi Közlemények 4 : 3 pp. 79-93.

[37] Müller, A. - Balatoni, I. - Csernoch, L. - Bács, Z. - Bíró, M. - Bendíková, E. - Pesti, A. - Bácsné, Bába, É. (2018), Asztmás betegek életminőségének változása komplex rehabilitációs kezelés után = Quality of life of asthmatic patients after complex rehabilitation treatment, Orvosi Hetilap 159: 27 pp. 1103-1112.

[38] Müller, A. - Barcsák, B. - Boda, J. E. (2016), Health tourism the cavebath of Miskolctapolca. In: György, Juhász; Enikő, Kocsmáros; Erika, Huszárik (szerk.) Korszerű szemlélet a tudományban és az oktatásban. Gazdaságtudományi szekció: Zborník medzinárodnej vedeckej konferencie Univerzity J. Selyeho - 2016 „Súcasné aspekty vedy a vzdelávania". Sekcie ekonomických vied. Komárno, Szlovákia : Selye János Egyetem, (2016) pp. 233-245. , 13 p.

[39] Müller, A. - Bíró, M. - Hídvégi, P. - Váczi, P. - Plachy, J. - Juhász, I. - Hajdú, P. - Seres, J. (2013), Fitnesz trendek a rekreációban, Acta Academiae Paedagogicae Agriensis Nova Series: Sectio Sport 40 pp. 25-34.

[40] Müller, A. - Kerényi, E. - Könyves, E. (2011), Effect of climate therapy and rehabilitation in Mátra Medical Institute Applied Studies in Agribusiness and Commerce, Apstract - Applied Studies In Agribusiness and Commerce 5 : 3-4 pp. 39-42.

[41] Müller, A. - Kerényi, E. (2009), Javuló életminőség és költséghatékonyság: A Mátrai gyógyintézet asztmás, szénanáthás és COPD-s betegei terápiás kezelésének hatásvizsgálata, Economica (Szolnok) 3. pp. 59-64. 
[42] Müller, A. - Könyves, E. - Szabó, R (2005): A wellnessturizmus sokszínű kínálatának bemutatása, ISKOLAI TESTNEVELÉS ÉS SPORT - ELMÉLETI MÓDSZERTANI ÉS INFORMÁCIÓS SZAKLAP 27. pp. 29-34.

[43] Müller, A. - Szabó, R. - Kerényi, E. - Mosonyi, A. (2009), Fürdőkutatás a Közép-dunántúli régióban, Acta Academiae Paedagogicae Agriensis Nova Series: Sectio Sport 36 pp. 77-87. , 11 p.

[44] Müller, A. - Szabó, R. (2009), Analysis of Agárd, Komárom and Papa's Thermal bath, According the Guest's satisfaction, Acta Academiae Paedagogicae Agriensis Nova Series: Sectio Sport 36. pp. 89-101.

[45] Müller, A. - Széles-Kovács, Gy. - Seres, J. - Kristonné, Dr. Bakos M. (2011), Főiskolai hallgatók rekreációs tevékenységei, REKREACIO.EU 1. : 4. pp. 31-34.

[46] Pratt, M. - Norris, J. - Lobelo, F. - Roux, L. - Wang, G., The cost of physical inactivity: moving into the 21st century, British Journal of Sports Medicine, 48, 2014, pp. 171-173.

[47] Salavecz Gy. (2008), Munkahelyi stressz és egészség, In: Kopp M. (szerk.) Magyar lelkiállapot 2008, Esélyerõsítés és életminõség a mai magyar társadalomban, Semmelweis Kiadó, Budapest, 288-297.

[48] Simon I. Á., Kajtár G., Herpainé Lakó J., \& Müller A. (2018), A fizikai aktivitás és a mentális egészség jelentősége a 60 év fölötti korosztály életében, Képzés És Gyakorlat: Training And Practice 16 : 1 pp. 25-36. , 12 p.

[49] Sport XXI. Nemzeti Sportstratégia 2007, Budapest.

[50] Nagy, A., - Tobak, J. (2014): Lakossági sportolási és sportfogyasztási szokások vizsgálata. Magyar Sporttudományi Szemle. 15(2):47.

[51] C. Pfau- S. Domonkos (2016). Szabadidősport a felsőoktatásban= Leisure sport activities in universities. TAYLOR, 8(2), 111-117.

[52] C. Pfau (2015). Analysis of the leisure sport activities in University of Debrecen. APSTRACT: Applied Studies in Agribusiness and Commerce, 9(1033-2016-84281), 75-80.

[53] Ráthonyi-Ódor, K. - Ráthonyi, G. - Borbély, A. (2016), Sportolni jó - felelősen a sport népszerüsítéséért. Agrártudományi Közlemények/Acta Agraria Debreceniensis:67 pp. 71-76. 6 p. (2016)

[54] Ráthonyi-Ódor, K. - Ráthonyi, G. - Földesi, B. - Urbánné, K. M. (2016): Sportközpontú CSR intézkedések értékelése. Acta Carolus Robertus Károly Róbert Főiskola Gazdaság- és Társadalomtudományi Kar Tudományos Közleményei 7:(1) pp. 233-247.

[55] Lengyel, A. (2015), Extending tourism's role in the tourism - meditation - creativity innovation - sustainability trajectory. In: Dunay, Anna (szerk.) Proceedings of the 5th International Conference on Management 2015 : Management, Leadership and Strategy for SMEs' Competitiveness. Gödöllő, Magyarország : Szent István Egyetemi Kiadó, (2015) pp. 543-548. , $6 \mathrm{p}$.

[56] Lengyel, A. (2019): A mindfulness és liminalitás felértékelődése: spirituális elvonulási központok, a fenntartható jövő desztinációi?TURIZMUS BULLETIN 19 : 1 pp. 14-24. , 11 p. 